\title{
Analysis of Social Responsibility Implementation Plan to Profitability Companies in Bank Syariah Mandiri
}

\author{
Rahmawati, Auliarahmi Ariesta, I Ketut Patra \\ Sekolah Tinggillmu Ekonomi Muhammadiyah Palopo, Indonesia \\ rahmawati345@yahoo.co.id
}

\begin{abstract}
This paper aims to describe Corporate Social Responsibility (CSR) is one of concern for a company on the environment. Currently CSR aims to maximize profits but are also required to better accommodate the needs of the community and its stakeholders. This study was conducted to provide empirical evidence of the influence of CSR to the company's profitability. Research was conducted on PT Bank SyariahMandiri. The Data used are the financial statements issued by the company each year during the period 2002-2013. This study uses a simple regression analysis results showed that during the period 2002-2013 cooperated with LAZNAS BSM BSM/organization partners in the distribution of alms fund companies and the implementation of programs that are Humanity. The program routine that has been Carried out Independently of Islamic banks is synergy Together LAZNAS, who consistently implement the People Partner program, Micro Development, development and economic empowerment of the people through the capital assistance, training and mentoring of individual businesses, educational assistance (scholarships) to Reviews those in need, help is Also included learning facilities, Community Development Program, Religious, Public Facility etc. Moreover in this study indicate that the implementation of CSR.
\end{abstract}

Keywords: Social responsibility, CSR implementation, profitability, Economic empowerment, Alms, Humanity

\section{Introduction}

The world of business is no longer just pay attention to the company's financial records (single bottom line), but also includes social and environmental aspects of the so-called triple bottom line. Synergy of these three elements is the key concept of sustainable development (Sustainable Development). The concept of Triple Bottom Line or "3P" (profit, people, and planet) translated by John Elkington in Wibisono (2007: 56) explains if the company wants to sustain, in addition to the pursuit of profit, the company must also give a positive contribution to society and actively participate in protecting the environment. Some companies actually have been doing CSA (Corporate Social Activity) or social activities of the company. Although not named as CSR, in fact the action closer to the concept of CSR which represents a form of participation and corporate concern for the social and environmental aspects. Through the concept of corporate social investment, since 2003 the Ministry of Social recorded as government agencies are active in developing the concept of CSR and advocate for various national companies. In the public marketplace of ideas, the term "corporate governance" has recently been described as "the set of processes, customs, policies, laws and institutions affecting the way in which a corporation is directed, administered or controlled." 12 Yet the substance attributed to this definition has changed quite dramatically over the past years, shifting from a functional, economic focus on agency problems within a private law sphere to a public policy approach that seeks to protect investors and nonshareholder stakeholders. The evolution in the perception of corporate governance reflects broad changes in the socio-legal view of business corporations (Gill, 2008).

Referring to Law No.40 / 2007 states, social and environmental responsibility is the company's commitment to participate in the sustainable economic development to improve the quality of life and environment is beneficial, both for the company itself, the local community and society at large. Law No. 40/2007 also said the company is conducting its business activities in the field and or related to the natural resources required to implement social and environmental responsibility. Islamic banking CSR program should actually touch the basic needs of the community to create equitable economic prosperity for society. On the argument above, this research is intended to perform an analysis of: Analysis of implementation of social responsibility Fund Company to profitability at PT. Bank Syariah Mandiri. 


\section{Literature Review}

Corporate social responsibility (CSR) disclosure has received an increasing amount of attention in both the academic and business fraternities. Such disclosure encompasses the provision of information on human resource aspects, products and services, involvement in community projects/activities and environmental reporting (Mohd-Ghazali, 2007).

Environment: The overall level of environment disclosure for Malaysian companies remained low despite government efforts and campaigns to improve the environment. Casual evidence suggests, however, that there are some companies that contributed to improve the environment but which did not disclose the fact in their annual reports. As a result, the users of the annual reports do not know and may conclude that the company did not do anything towards the protection of the environment (Jamil, Alwi\& Mohamed, 2002), The company will acquire social legitimacy and maximize long-term financial strength through social programs and maximize its financial strength in the long term through the application of CSR. If something similar happened in the banking company, especially in this case Islamic banking. Agency theory and Signalling rooted in the idea of asymmetric information, which says that in some economic transactions, inequalities in access to information to the normal market for the exchange of goods and services. Measure both the space and the quality of CSR disclosures, including in the latter a measure based on informational quality attributes as discussed by the Inter- national Accounting Standards Board, the Financial Accounting Standards Board, and the Global Reporting Initiative. We find significant increases in the space allocated to CSR disclosure, as well as some evidence of increased quality; although the informational quality of the disclosures remains quite low and fewer firms are including J.-N. Chauvey, S. Giordano-Spring Montpellier Research in Management, ISEM, Universite negative performance information in their reports. Finally, we document that differences in disclosure space and quality in 2004 appeared to be associated with legitimacy based variables and that those relations remain largely unchanged in 2010. As such, it appears that the NRE's goals of increased transparency remain unmet (Chauvey, Giordano-Spring, Cho\& Patten, 2015).

Profitability and Using a quasi-natural experiment that mandates a subset of listed firms to issue corporate social responsibility (CSR) reports, this paper examines the effect of mandatory CSR disclosure on market information asymmetry in China, where we estimate information asymmetry using high- frequency trade and quote data. We find that contrary to the criticism that mandatory CSR disclosure lacks credibility and relevance in emerging markets, mandatory CSR reporting firms experience a decrease in information asymmetry subsequent to the mandate. In addition, the decrease in information asymmetry is more pronounced among firms with greater political/social risks, poorer information environments, and better CSR reporting quality. Additional analyses suggest that relative to mandatory CSR disclosure, voluntary CSR disclosure is part of a firm's political/social strategy and has higher CSR reporting quality. However, the effect of voluntary CSR disclosure on information asymmetry is limited unless CSR reporting is widespread(Shi, Hung, \& Wang, 2015). There has been little attempt to develop a model that can evaluate CR in diverse environments with differing regulatory and market settings. I attempt to fill this gap by developing a conceptual framework that focuses on legal systems and is tested empirically in the European context. My results confirm the validity of this conceptual framework in the European environ? The analysis of CER shows a direct correlation between intense regulation and high corporate ratings. With regard to CSR, the findings are more ambiguous; while civil and German civil laws significantly influence CSR, common and Scandinavian civil laws do not. Furthermore, mean test results indicate that corporate social rating averages differ only slightly across the countries of Europe, despite a variety of legal systems. This article suggests ways to interpret this finding. Second, this study adds to the sparse but growing literature that assesses the links between CR and corporate financial performance on the European market. Most relevant research focuses on the US market. One reason why earlier studies have not considered the effect of financial performance on CR in the European market is that CR data for European firms are produced by very few rating agencies and are not widely available (Ce, 2011). In this study, the company's profitability measured by return on assets ratios derived from financial data which is the object of research over the period 2002 to 2013. This ratio is a ratio that is important to determine the profitability of a company. Return on assets is a measure of the effectiveness of the company in generating profits by exploiting its assets. By calculating ROA as follows: 
Return on Assets $(\mathrm{ROA})=\underline{\text { Net of Income }}$

Total Assets

CSR is an agreement of the World Business Council for Sustainable Development (WBCSD) in Johannesburg South Africa in 2002 which aimed to encourage all companies of the world in order to create a sustainable development (sustainable development), working with the company's employees, their families, communities and the local community as a whole in improved quality of life. More specifically, we show (1) the breadth of CSR disclosure (using two different measures of disclosure extensiveness) has grown dramatically, (2) that there is no significant change in the relation between legitimacy variables and differences in CSR disclosure, and (3) that differences in CSR disclosure (using either of the breadth measures) were not significant in explaining differences in the market value of firms in the late 1970s and continue to be insignificant today. In general, our results suggest that CSR disclosure, while more extensive today than it had been three decades ago, fails to provide information that is relevant for assessing firm value (Bott, 2014). According to Nafarin (2007: 46) budget is a financial plan drawn up periodically by the programs that have been approved.

Budget (budget) is a written plan about the activities of an organization that planned quantitative and generally expressed in units of money for a certain period. Based on the proportion of corporate profits and the amount of the CSR budget, Sudharto (2008) divides companies into four categories. Although it tends to simplify reality, this typology illustrates the ability and commitment of the company in implementing CSR. Exist Edwin (2010) examined the tanggug Social Responsibility at BNI Syariah Banking Organization, while the form of social responsibility undertaken by BNI Syariah is oriented to the social sector, especially education sector. Sources of funding of social responsibility activities undertaken BNI Syariah is derived from partial profits. Besides donations from employees and funds from Alms Service Unit (UPZ) BNI Syariah also a source of funds for the implementation of CSR activities in BNI Syariah. Titofianti (2012) Implementation of Corporate Social Responsibility (CSR) Pt. Bank Rakyat Indonesia Tbk. CSR Implementation Unit Office Porong BRI Unit in 2011 focused on Community Development Program in the form of BRI Cares Program Pasar Rakyat (FAST) held in Porong Market. BRI conducted PESAT program, which complements the infrastructure and facilities required by the market and management of waste management is waste management well. Tsoutsoura research results (2004) indicate that the relationship CSR with financial performance (as seen from the ratio of profitability ROA, ROE, and ROS) is positive and statistically significant. It means that there is a positive association between CSR and profitability.

\section{Methodology}

This research was conducted at PT. Bank SyariahMandiri, located at the branch office in JalanAndiDjemma Palopo 4 Palopo, South Sulawesi province of Indonesia. To analyze and interpret the data properly, the necessary data is accurate and systematic so that the results obtained were able to describe the situation of the object being studied properly. In the data collection phase, data collection techniques used in this study are: Population and Samples, In this study population used is independent Islamic Bank's annual report for the past 12 years, because of the small number of the population owned causes the population as well as a sample in this study. The type of data used in this research is quantitative data, i.e. data obtained and presented in the form of figures. Data mentioned from of calculation the amount of budget and realization from year to year, addition in this study also uses data from interviews in the form of statements from informants in this case the bank officials who already have the capability field, the authors obtained information in the form of the action of the activities liability social responsibility by Bank SyariahMandiri based on annual reports that have been published. Analysis of the data used in this study is a simple linear regression analysis, using SPSS version 21. Before performing a linear regression analysis, first tested the classical assumption of regression in order to obtain good results, among the classical assumption used is normality test on the model regression, Test and Test Heteroskedastity autocorrelation. Descriptive statistics provide a picture or description of a data seen from the average value (mean), standard deviation, variance, maximum, minimum and range. Simple linear regression analysis was analysis to measure the influence of the independent variables with the dependent variable and the dependent variable predicted by using the independent variable. In simple linear regression are the classical assumptions that must be met, namely the residuals are normally distributed, the absence of heteroscedasticity and the absence of autocorrelation in 
the regression model.

$Y=a+b X+\mathrm{e}$

Where:

Y: Profitability Company

$\mathrm{X}$ : Implementation of CSR

A: Constants

b: Regression Coefficients

e: Error term

\section{Research Finding}

Descriptive statistics in this study aims to provide an overview of the data that has been processed consisting of frequency, mean and standard deviation. The following descriptive data table:

Table 1: Descriptive Statistics

\begin{tabular}{llll}
\hline & Mean & Std. Deviation & N \\
\hline Profitability & 25.5833 & 1.31137 & 12 \\
Implement CSR & 21.6667 & 1.82574 & 12 \\
\hline
\end{tabular}

SPSS Version 21.02015

Based descriptive research data in Table 1 can be seen that all the variables have 12 samples; at a variable profitability company has an average value of 25.58 with a standard deviation of 1.31 . While the implementation of CSR have variable average value of 21.66 with a standard deviation of 1.82 . Hence although significant, the influence of return-on-as? sets on CER remains relatively limited. The cash-to assets variable had no significant impact on CSR. These results offer some support to the slack resources "Firms with slack resources theory (Ce, 2011), As more and more multi-national companies their domiciled country but also their corporate response expand their operations globally, their responsibilities extend abilities now include cross-national issues as well. Various beyond not only the economic motive of profitability but also stakeholders are beginning to emphasize or expect more other social and environmental factors. The objective of these social responsibilities from companies.

a. Normality Test: Normality test results showed that the residual value is already normally distributed. This is shown by drawing P-Plot which shows that the point is not far from the diagonal line. The results of the normality test with P-plot diagram is as follows: From the graph it can be seen that points out spread around the line and follow the diagonal lines of the residual value has been normal.

b. Test heteroskedastisity: A good regression model is not the case heteroskedastisity. And as for the means used to determine whether free of heterokedastisity with Spearman's rho, which correlate with the independent variables unstandardized residual value, the test using a 0.05 significance level if correlations between independent variables with significant residual can be more than 0.05 , it can be said heteroskedastisity problem does not occur in the regression model.

Table 2: Uji Durbin- Watson (DW test), Model Summaryb

\begin{tabular}{llllll}
\hline Model & $\mathbf{R}$ & R Square & \multicolumn{2}{c}{$\begin{array}{c}\text { Adjusted R SquareStd. Error } \\
\text { Estimate }\end{array}$} & of theDurbin-Watson \\
\hline 1 & $.810^{\mathrm{a}}$ & .656 & .622 & .80651 & 2.273 \\
\hline
\end{tabular}

a. Predictors: (Constant), implements csr

b. Dependent Variable: profitability

Based on the table above 2 indicates that the value of Durbin Watson 2.273 (being around the numbers -2 to +2 ), it can be said that the regression model free of classical assumption autocorrelation. 


\section{Hypothesis Testing}

a. Simple regression test, Regression analysis was performed after classical assumption has been met, where the data entered is normal or free from multicollinearity and heteroscedasticity so it will not lead to biased data. Regression analysis was performed to determine the effect between the independent variables and the dependent variable. In this study the analysis is simple regression enter method by inserting the whole variable so it can be seen how much influence the independent variable on the dependent variable. Below is a table entering with SPSS version 21:

Table3: UjiRegresi Linear Sederhana, Coefficients ${ }^{a}$

\begin{tabular}{llll}
\hline & & \multicolumn{2}{c}{ Unstandardized Coefficients } \\
& & B & Std. Error \\
\hline 1 & (Constant) & 12,977 & 2,895 \\
& implementscsr &, 582 &, 133 \\
\hline
\end{tabular}

a. Dependent Variable: profitability

Based on the table above, the simple linear regression equation is as follows: $\mathrm{Y}=12.977+0,582 \mathrm{X}$

From the results table above can be explained as follows: Value constants (a) is equal to 12.977, meaning that if the implementation of CSR's value is 0 , then the level of profitability in value by 0.582.2) Value Variable Regression Coefficients CSR Implementation is 0.582 , this may mean that any increase in CSR implementation by $1 \%$, then the rate of profitability also will increase by $0.582 \%$. T test is used to determine whether the independent variables have a significant effect (real) or not on the dependent variable in this case to determine whether the variables significantly influence the implementation of CSR or not on the profitability of the company. The degree of significance used was 0.05 . If the value is significantly smaller than the degree of confidence then we accept the alternative hypothesis, which states that independent variables affect the dependent variable. Here is a hypothesis that will be tested: H1: the implementation of social responsibility funds tanggunng significant effect on the profitability of the Company.

Table 4: Uji T (T Test), Coefficients ${ }^{\mathrm{a}}$

\begin{tabular}{|c|c|c|c|c|c|c|}
\hline \multirow[t]{2}{*}{ Model } & & \multicolumn{2}{|c|}{$\begin{array}{l}\text { Unstandardized } \\
\text { Coefficients }\end{array}$} & \multirow{2}{*}{\multicolumn{2}{|c|}{$\begin{array}{l}\text { Standardize T } \\
\text { d } \\
\text { Coefficients } \\
\text { Beta }\end{array}$}} & \multirow[t]{2}{*}{ Sig. } \\
\hline & & B & Std. Error & & & \\
\hline \multirow{2}{*}{1} & (Constant) & 12.977 & 2.895 & & 4.482 & .001 \\
\hline & implementscsr & .582 & .133 & .810 & 4.368 & .001 \\
\hline
\end{tabular}

a. Dependent Variable: profitability

Based on the table above can explain the results of the test $\mathrm{T}$ (test) as follows by comparing $\mathrm{t}$ arithmetic and $\mathrm{t}$ table where $\mathrm{t}$ table $(\mathrm{N}-2=12-2=10)$ is equal to -1.812 . $\mathrm{T}$ arithmetic csr implementation of 4.368 with a significance level of 0.001 . T count $>t$ table $(4.368>-1.812)$ and with significant value $<0.05(0.001<0.05), \mathrm{H} 0$ is rejected and $\mathrm{H} 1$ accepted, it indicates that the implementation of CSR variables significantly affect the profitability of the Company. The results are consistent with the results of research McGuire, Sundgren and Schneeweis (1988) that there was a significant positive correlation between CSR to company profitability.

Analysis Correlation Coefficient and the coefficient of determination (R2): The correlation coefficient R showing how much correlation or relationship between the dependent and independent variables. The correlation coefficient $R$ value is said to be strong if it is above 0.5 and close to 1 . Here is the output of a model summary: 
Table5: Correlation dan Coefficient Determinasi, Model Summaryb

\begin{tabular}{llllllr}
\hline Model & $\mathbf{R}$ & R Square & Adjusted R Square & $\begin{array}{l}\text { Std. Error of the } \\
\text { Estimate }\end{array}$ & of \\
\hline 1 & $.810^{\mathrm{a}}$ & .656 & .622 & .80651 & \\
\hline
\end{tabular}

a. Predictors: (Constant), implement scsr

b. Dependent Variable: profitability

Output SPSS 21.0, 2015

a. R in simple linear regression analysis showed modest correlation (correlation person), which is the correlation between the independent variable on the dependent variable. Figures $\mathrm{R}$ in the can on the table is equal to 0.810 means that the correlation between the variable implant csr with variable profitability of the company amounted to 0.810 . This means there is a very close relationship because the value closes to 1.

b. R Square (R2) or square of R, which shows the value of the coefficient of determination. This figure will be converted into the form of percent, which means the percentage contribution of the influence of the independent variable on the dependent variable. As much as 0,656 R2 value means the percentage contribution of implementing csr variable influence on the profitability of the company by $65 \%$, while the rest influenced by other variables that are not entered in this model. Adjust $\mathrm{R}$ Square, is the adjusted R-square value of 0622 , this also shows the contribution of the influence of the independent variable on the dependent variable. Adjust $\mathrm{R}$ Square is usually to measure the contribution of influence if the regression using more than two independent variables.

c. Standard error of the estimate, is a measure of prediction error, a value of 0.80651 , meaning that errors in predicting the profitability of $0.80651 \%$.

\section{Conclusion}

The purpose of this study was to examine the implementation of the Fund How Social responsibility PT Bank SyariahMandiri and its influence on the company's profitability in the period 2002-2013. Based on the discussion of the results of empirical research that has been described, the researchers took the following conclusion: In the implementation of CSR implementation, BSM cooperating with LAZNAS BSM/Organization Partners in the distribution of alms fund companies and the implementation of programs that are Humanity. BSM realize that CSR (Corporate Social Responsibility/CSR) are important in supporting the growth of the company. Bank consistently implement Corporate Social Responsibility (CSR) as a form of concern to the company as well as the appreciation of the people who have given the trust and support of the Islamic banking business, as for the regular program that has been carried out independently of Islamic banks is 1) synergy LAZNAS Together, the Partners program race, Micro Development, development and economic empowerment of the people through the capital assistance, training and mentoring of individual businesses. Educate People Providing educational assistance (scholarships) to those in need and to seek the persistence of teaching and learning activities. Help also includes learning facilities, 2) Community Development Program, 3) Religious, 4) Public Facilities etc. In this study indicate that the implementation of csr influential significance of 0.001 . Tcount $>t$ table $(4.368>-1.812)$ and with significant value $<0.05(0.001<0.05)$ then this indicates that the implementation of CSR variables significantly affect the profitability of the Company. This shows that the higher costs incurred by CSR PT Bank SyariahMandiri, making the company's relationships with surrounding communities and the environment as well as the consumer will get better, it allows an increase in sales (Januarti, 2005). With further ensure the well-being of employees will make the employees more loyal and passion in doing his job, so the company's objectives in the long term can be achieved.

Limitations Research: This study has many limitations that require repair for further research. The limitations experienced in this study are the lack of the number of samples and the object of research. It is also still not being generalized and cannotrepresents all existing companies. The study also only uses the dependent variable profitability calculated using return on Assets (ROA) only. These results provide additional empirical evidence about the phenomenon of CSR, especially in Indonesia, and Based on the limitations described above, further research is expected to increase the number of samples and extend the observation time so that further research could generalizable.Research can replace or supplement a proxy 
profitability, e.g. ROE, ROI or ROS, and the independent variables plus or using other variables that potentially contribute to the profitability of companies such as CSR Performance (Measure by KLD index) as a measure of CSR.

\section{References}

Bott, R. (2014). No Title No Title. Igarss 2014, (1), 1-5. http://doi.org/10.1007/s13398-014-0173-7.2

Ce, G. (2011). Exploring the Impact of Legal Systems and Financial Structure on Corporate Responsibility. Journal of Business Ethics, 95, 195-222. http://doi.org/10.1007/s10551-011-0854-5

Chauvey, J. N., Giordano-Spring, S., Cho, C. H.\& Patten, D. M. (2015). The Normativity and Legitimacy of CSR Disclosure: Evidence from France. Journal of Business Ethics, 130(4), 789-803. http://doi.org/10.1007/s10551-014-2114-y

Edwin. (2010).Meneliti mengenai Tanggug Jawab Sosial Pada Organisasi Perbankan BNI Syariah

Gill, A. (2008). Corporate Governance as Social Responsibility: A Research Agenda. Berkeley J. Int'l L., 26(2), 452-478. http://doi.org/10.15779/Z38MS9P

Jamil, C. Z. M., Alwi, K.\& Mohamed, R. (2002). Corporate social responsibility disclosure in the annual reports of Malaysian companies: A longitudinal study. Social and Environmental Accountability Journal, 22(2), 5-9.

Mohd Ghazali, N. A. (2007). Ownership structure and corporate social responsibility disclosure: some Malaysian evidence. Corporate Governance: The International Journal of Business in Society, 7(3), 251266. http://doi.org/10.1108/14720700710756535

Shi, J., Hung, M.\& Wang, Y. (2015). Mandatory CSR Disclosure and Information Assymetry: Evidence from a Quasi-natural Experiment in China.

McGuire, J. B., Sundgren, A. \& Schneeweis, T. (1988). Corporate Social Responsibility and Firm Financial Performance. Academy of Management Journal, 31(4), 854-872.

Nafarin, M. (2007). Penganggaran PerusahaanEdisi 3. SalembaEmpat. Jakarta.

Sudharto, E.(2008). What is and Benefits for Corporate," DisampaikanpadaSeminarDuaHariCSR : Strategy, Management, and Leadership. Jakarta 13-14Februari 2008.

Titofianti. (2012). Implementasi Corporate Social Responsibility (Csr) Pt. Bank Rakyat Indonesia Tbk.

Tsoutsoura, M.(2004). Corporate Social Responsibility and Financial Performance, Haas School of Business University of California at Berkeley.

Wibisono, Y. (2007). MembedahKonsepdanAplikasi CSR. ASHKAF Media Grafika. Surabaya.

Undang-Undang, Republik Indonesia Nomor 40, Tahun 2007 tentang Perseroan Terbatas.

UU No. 25 Tahun 2007 tentangPenanaman Modal

http://www.csrindonesia.com/activity.php. Kegiatan CSR Indonesia. (20 December 2014).

http://www.bsm.co.id/csr.php. Corporate Social Responsibility. (19 January 2015).

http://www.antaranews.com

http://komunikasia.net 